\title{
Lhermitte Duclos Disease in the Absence of Cowdens - A Varied Presentation
}

\author{
Rajesh Parameshwaran Nair ${ }^{1}$, Vinod Kumar ${ }^{2}$, Deopujari $\mathrm{CE}^{3}$ and Bhavna Nayal ${ }^{*}$ \\ ${ }^{1}$ Senior Registrar of Neurosurgery, KMC, Manipal University, Manipal, India \\ ${ }^{2}$ Associate Professor of Neurosurgery, KMC, Manipal University, Manipal, India \\ ${ }^{3}$ Professor and Head of Neurosurgery, Bombay Hospital and Medical Research Centre, India \\ ${ }^{4}$ Associate Professor, Department of Pathology, KMC, Manipal University, Manipal, India
}

*Corresponding author: Bhavna Nayal, Associate Professor, Department of Pathology, Kasturba Medical College, Manipal University, Manipal 576104, India. Tel: 91-9611519911; E-mail: bhavnayal@yahoo.com

Received date: November 27, 2015; Accepted date: January 27, 2016; Published date: January 29, 2016

Copyright: (C) 2016 Nair RP, et al. This is an open-access article distributed under the terms of the Creative Commons Attribution License, which permits unrestricted use, distribution, and reproduction in any medium, provided the original author and source are credited.

\begin{abstract}
Background: Lhermitte-Duclos is a rare hamartomatous lesion of the cerebellar cortex with both neoplastic and hamartomatous features. Also known as dysplastic cerebellar gangliocytoma, they usually occur in the setting of Cowden's syndrome, an autosomal dominant condition characterized by multiple hamartomas and neoplastic lesions in skin and internal organs. Although enlargement of the internal granular layer of the cerebellum is a consistent finding in our case, the background setting of Cowden's syndrome was not present in our case.
\end{abstract}

Case description: We present a unique case of LDD in the absence of Cowdens syndrome in a 58-year old gentleman who presented with cerebellar signs, a first to be reported in literature. Here we describe our clinical vignette.

Conclusion: Most of the cases of LDD, reported in literature, were associated with Cowdens disease, however our case is the first to present without Cowdens disease. To date no other similar cases have been reported in literature.

Keywords: Lhermitte-duclos disease; Dysplastic gangliocytoma; Cowden syndrome; Cerebellar lesion

\section{Introduction}

Lhermitte-Duclos is a rare hamartomatous lesion of the cerebellar cortex with both neoplastic and hamartomatous features. Also known as dysplastic cerebellar gangliocytoma, they usually occur in the setting of Cowden's syndrome, an autosomal dominant condition characterized by multiple hamartomas and neoplastic lesions in skin and internal organs. Although enlargement of the internal granular layer of the cerebellum is a consistent finding in our case, the background setting of Cowden's syndrome was not present in our case.

They can cause symptoms and signs of mass effect in the posterior fossa and lead to hydrocephalus, brain herniation, and death, if not treated.

Clinical and pathological diagnosis can sometimes be challenging and it is of extreme importance for the pathologist to be aware of the variable clinical and histopathological presentations of such a rare lesion particularly to differentiate it from the low-grade glial and neuronal tumors.

Accurate preoperative diagnosis of Lhermitte-Duclos disease can be made on the characteristic magnetic resonance imaging appearances. Pathological diagnosis of Lhermitte-Duclos disease can be extremely difficult in the absence of proper clinical information and the pathologist should be watchful for any irregularity in the internal granular layer in evaluating the cerebellar tissue, which is otherwise normal.

\section{Case Report}

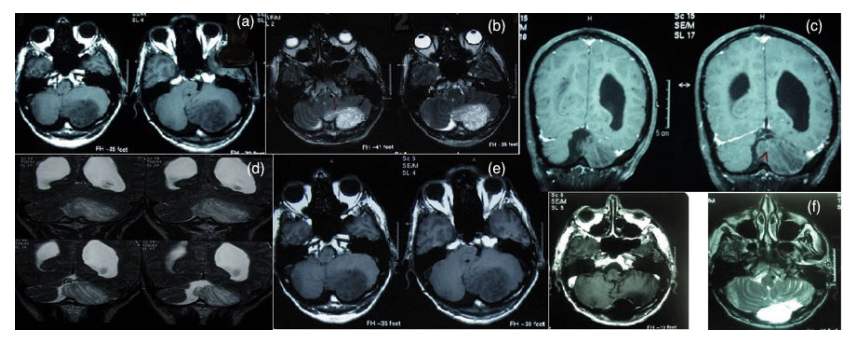

Figure 1: Preoperative and postoperative magnetic resonance imaging of the brain (MRI Brain) showing the following, preoperative TIW (a) series showing a well circumscribed, hypointense lesion in the left cerebellar hemisphere, hyperintense "tiger-striped" lesion on T2W (d) with no enhancement on contrast. (c) The last section of the figure shows a postoperative MRI showing post excision status, with $\mathrm{T} 1$ (e) and $\mathrm{T} 2 \mathrm{~W}$ (f) showing gross total excision of tumor.

A 58 year-old gentleman presented to our outpatient department with history of giddiness since 3 months, imbalance while walking since 2 months and holocranial headache since 2 months. The 
Citation: Nair RP, Kumar V, Deopujari CE, Nayal B (2016) Lhermitte Duclos Disease in the Absence of Cowdens - A Varied Presentation. J

Page 2 of 3

headache was more in the morning and associated with blurring of vision at the peak of headache. On examination he had bilateral grade 1 papilledema and left side cerebellar signs with impaired tandem walking. Preoperative magnetic resonance imaging (MRI) of the brain showed a well circumscribed, hypointense lesion in the left cerebellar hemisphere, hyperintense "tiger-striped" lesion on T2W with no enhancement on contrast (Figure 1a-d). There was the typical nonenhancing gyriform pattern of enlargement of cerebellar folia. The characteristic imaging pattern obviated the need for any other differential diagnosis. He underwent a suboccipital craniotomy with gross total excision of the tumor with Ommayya reservoir placement (Figures 2-4). Postoperative MRI showed gross total excision of tumor and patient improved significantly with gross reduction in ataxia and giddiness (Figure 1e and 1f). Histopathological examination, proferred a diagnosis of Lhermitte Duclos disease (Figure 5).

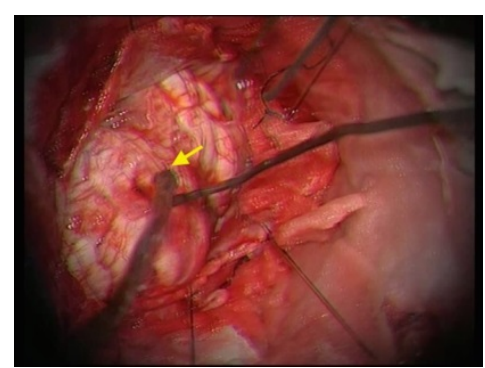

Figure 2: Intraoperative image (yellow arrow) showing diseased cerebellum.

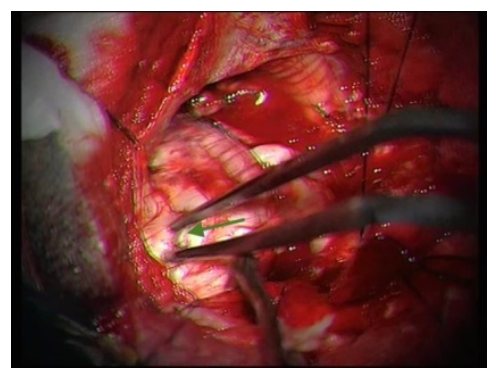

Figure 3: Intraoperative image showing (green arrow) resection of diseased cerebellum.

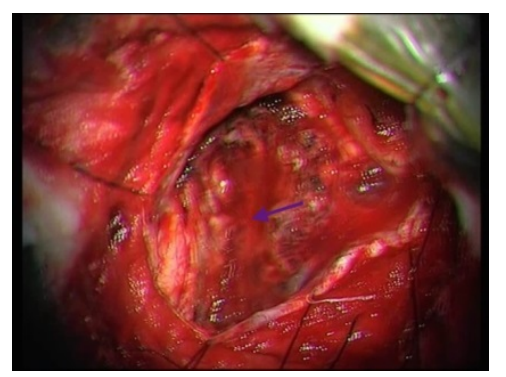

Figure 4: Intraoperative image showing post resection tumor bed (purple arrow).

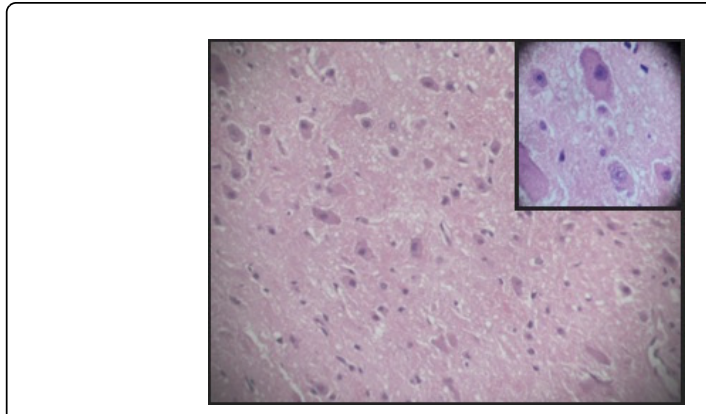

Figure 5: Broadened molecular layer with disappearance of Purkinje cells and progressive hypertrophy of the granular cells with loss of central white matter core of the cerebellar foliae.

\section{Discussion}

Dysplastic gangliocytoma (Lhermitte Duclos Disease), first described by Jacques Jean Lhermitte and P Duclos in 1920 [1-4], is a rare entity with only 220 cases reported in literature [5-9]. It usually affects the cerebellum and manifests in young adults though it can present from birth to sixth decade of life. The nature of this lesion remains unclear, however, hamartoma/hypertrophy accounts for most of the nomenclatures of this disease. Typically, patients present with headache, cerebellar dysfunction, occlusive hydrocephalus and cranial nerve palsies $[3,4,9,10]$. It is often associated with Cowden syndrome and is pathognomonic for this disease. It usually presents as a progressive lesion in the posterior fossa with surgical excision being the mainstay of treatment.

Cowden syndrome (Multiple hamartoma syndrome) is associated with mucocutaneous lesions and a strong association with breast, thyroid and endometrial cancers [2,4]. Various diagnostic criteria have been described for Cowdens (Table 1). These patients demonstrate a germline mutation in the PTEN gene. MRI brain has revolutionized the early detection and diagnosis of this entity. The T1W images typically show a hypointense, non-enhancing lesion with $\mathrm{T} 2 \mathrm{~W}$ images showing a high intensity lesion with a characteristic "tiger-striped" pattern [11,12]. Padberg et al. [13] described the association of LDD with CD in 1991. He stated that they both were a single phakomatosis and in the presence of LDD, the diagnostic criteria for CS are fulfilled if one other major manifestation of CS or three minor criteria are present.

The first successful surgery for LDD was performed in 1937 in a 34 year-old man who had experienced intermittent symptoms for 6 years. By 1955, only three patients had survived surgery for LDD. One third of the 90 patients diagnosed with LDD, before 1994, had died of the complications of their disease $[14,15]$.

Most of the cases of LDD, reported in literature, were associated with Cowdens disease, however our case is the first to present without Cowdens disease. To date no other similar cases have been reported in literature. 
Citation: Nair RP, Kumar V, Deopujari CE, Nayal B (2016) Lhermitte Duclos Disease in the Absence of Cowdens - A Varied Presentation. J Neurol Disord 4: 260. doi:10.4172/2329-6895.1000260

Page 3 of 3

\begin{tabular}{|c|c|c|c|c|}
\hline \multicolumn{5}{|c|}{ Criteria for diagnosis of Cowden disease } \\
\hline Mucocutaneous lesions & Major & Minor & $\begin{array}{l}\text { Working diagnosis (w/no family } \\
\text { history) }\end{array}$ & $\begin{array}{l}\text { Working diagnosis in a family } \mathrm{w} / 1 \text { person } \\
\text { in whom cowden disease }\end{array}$ \\
\hline Facial trichilemmomas & Breast cancer & $\begin{array}{l}\text { Noncancerous thyroid } \\
\text { lesions }\end{array}$ & $\begin{array}{l}\text { Mucocutaneous lesion alone } \\
\geq 6 \text { facial papules, of which } \geq 3 \text { must be } \\
\text { trichilemmomas, or cutaneous facial } \\
\text { papules plus oral mucosal papillomatosis, } \\
\text { or oral cutaneous papillomatosis and acral } \\
\text { keratosis or } \geq 6 \text { palmoplantar keratoses }\end{array}$ & $\begin{array}{l}\text { Pathognomonic criteria } \\
1 \text { major criterion }\end{array}$ \\
\hline Acral keratosis & Thyroid cancer & $\begin{array}{l}\text { Cognitive delay } \\
(\mathrm{IQ} \leq 75)\end{array}$ & 2 major criteria & 2 minor criteria \\
\hline Papillomatous papules & Macrocephaly & $\begin{array}{l}\text { Gastrointestinal } \\
\text { hamartomas }\end{array}$ & 1 major and 3 minor criteria & $\begin{array}{l}\text { History of Bannayan-Riley-Ruvalcaba } \\
\text { syndrome }\end{array}$ \\
\hline \multirow[t]{5}{*}{ Mucosal lesions } & $\begin{array}{l}\text { Endometrial } \\
\text { cancer }\end{array}$ & $\begin{array}{ll}\text { Breast } & \text { fibrocystic } \\
\text { diseasel } & \end{array}$ & 4 minor criteria & \\
\hline & & Lipomas, fibromas & & \\
\hline & & $\begin{array}{l}\text { Genitourinary tumors } \\
\text { (renal cell cancer) }\end{array}$ & & \\
\hline & & $\begin{array}{l}\text { Genitourinary } \\
\text { manifestations }\end{array}$ & & \\
\hline & & Uterine fibroid tumors & & \\
\hline
\end{tabular}

Table 1: Diagnostic criteria for Cowdens disease.

\section{References}

1. Lhermitte J, Duclos P (1920) Sur un ganglionneurome diffuse du cortex du cervelet. Bull Assoc Fr Etud Cancer 9: 99-107.

2. Braud AC, de Rocquancourt A, Marty M, Espie M (1999) Cowden disease and Lhermitte Duclos disease, markers of breast carcinoma: report of two patients. Ann Oncol 10: 1241-1243.

3. Vantomme N, Van Calenbergh F, Goffin J, Sciot R, Demaerel P, et al. (2001) Lhermitte-Duclos disease is a clinical manifestation of Cowden's syndrome. Surg Neurol 56: 201-204.

4. Vinchon M, Blond S, Lejeune JP, Krivosik I, Fossati P, et al. (1994) Association of Lhermitte-Duclos and Cowden disease: report of a new case and review of the literature. J Neurol Neurosurg Psychiatry 57: 699-704.

5. Moonis G, Ibrahim M, Melhem ER (2004) Diffusion-weighted MRI in Lhermitte-Duclos disease: report of two cases. Neuroradiology 46: 351-354.

6. Nowak DA, Trost HA (2002) Lhermitte-Duclos disease (dysplastic cerebellar gangliocytoma): a malformation, hamartoma or neoplasm? Acta Neurol Scand 105: 137-145.

7. Padberg GW, Schot JD, Vielvoye GJ, Bots GT, de Beer FC (1991) Lhermitte-Duclos disease and Cowden disease: a single phakomatosis. Ann Neurol 29: 517-523.

8. Kumar N, Kumar A, Uppin M (2016) Lhermitte-Duclos disease as a cranial manifestation of Cowden syndrome. Neurol India 64: 162-164.
9. Stepniak, Trojanowski T, Drelich-Zbroja A, Willlems P, Zaremba J (2015) Cowden Syndrome and the associated Lhermitte-Duclos disease - Case presentation. Neurol Neurochir Pol 49: 339-343.

10. Molvi M, Sharma YK, Dash K (2015) Cowden Syndrome: Case Report, Update and Proposed Diagnostic and Surveillance Routines. Indian J Dermatol 60: 255-259.

11. Abel TW, Baker SJ, Fraser MM, Tihan T, Nelson JS, et al. (2005) Lhermitte-Duclos disease: a report of 31 cases with immunohistochemical analysis of the PTEN/AKT/mTOR pathway. J Neuropathol Exp Neurol 64: 341-349.

12. Awwad EE, Levy E, Martin DS, Merenda GO (1995) Atypical MR appearance of Lhermitte-Duclos disease with contrast enhancement. AJNR Am J Neuroradiol 16: 1719-1720.

13. Backman SA, Stambolic V, Suzuki A, Haight J, Elia A, et al. (2001) Deletion of Pten in mouse brain causes seizures, ataxia and defects in soma size resembling Lhermitte-Duclos disease. Nat Genet 29: 396-403.

14. Arun KA, Sreejith R, Hitha B, Geetha P, Sasidharan PK (2015) Cowden syndrome with Lhermitte- Duclos disease presenting as ataxia. Natl Med J India 28: 74-76.

15. Matsumoto H, Minami H, Yoshida Y (2015) Lhermitte-Duclos Disease Treated Surgically in an Elderly Patient: Case Report and Literature Review. Turk Neurosurg 25: 783-787. 